\title{
The Determinants of a Successful Family Business Succession in Indonesia: A Multiple Case Study
}

\author{
Suresh Kumar \\ President University, Indonesia \\ sureshkumar@president.ac.id \\ Qireina Prameswari \\ Accenture, Malaysia \\ qireip@gmail.com
}

\begin{abstract}
Family businesses play an important role in both developed and developing countries. They employ a majority of workforce establishing the newest jobs and generating a significant proportion of the gross domestic product. About $96 \%$ of the 165,000 companies established in Indonesia are family businesses. However, the survival rate of passing through the stage of second generations in family business is very low. This research has been conducted to analyse the determinants of successful family business successions. Qualitative research method was used to study four families. The conclusion from the study was that the determinants of successful family business succession are managing a complex relationship of successors and incumbent related factors, family context, business context, and having a structured agreement system.
\end{abstract}

Keywords: Family Business, Successor-Related Factors, Incumbent-Related Factors, FamilyContext Related Factors, Business-Context Decisions, Structured-Agreement System

\section{Introduction}

It is known that worldwide businesses, between 65 and 80 percent, are owned by family businesses (Maciel, de la Garza Ramos, Aguilar, \& Reyna, 2015), contribute between 70 percent and 90 percent of global GDP, provide jobs globally between 50 percent and 80 percent, and responsible to 85 percent establishment of start-up companies. Family businesses in Indonesia are developing and experiencing rapid development nowadays. Approximately, there are approximately 96 percent of the 165,000 companies in Indonesia established in the form of family business (Angelina \& Indriyani, 2013). Hence, they become the major contributor to job seekers. The survival rate of family businesses is very low compared to non-family firms, even though family businesses are as important as they are driving force behind economic development (Bozer, Levin \& Santora, 2017). There is Chinese proverb that says, "Wealth does not pass three generations". The first generation makes the wealth, the second generation lives off of it, and the third generation squanders it. This is validated by world-wide statistics, which indicate that a mere $30 \%$ of family businesses survive into the second generation, with a worsening rate of $15 \%$ into the third and less than 3\% into the fourth (Poza, 2010; Bizri, 2016; Bozer, Levin, \&Santora, 2017). As an evidence in Indonesia, there are several 
successful family business successions, most notably; the Meneer's family (PT Nyonya Meneer), the Sadino's Family (Kemfood \& Kemchick), the Bakrie's family (Bakrie Group) and the Tanjung's family (Para Group). All these businesses are significant contributors to Indonesia prosperity, as they generate large amounts of revenue and create numerous jobs. Unfortunately, PT Nyonya Meneer was declared bankrupt on August 3rd, 2017 due to descendants' conflict and financial problem.

Furthermore, there were several other family businesses that did not manage to survive in intergenerational transitions such as, Bank NISP, PT Bentoel Internasional Investama Tbk, and PT HM Sampoerna Tbk. Hence, the number of family businesses that manage to survive in intergenerational transition are not very high as well in Indonesia. This evidence brings us to a research question "What elements of the succession process do these families and others manage in order to successfully transcend into the second generation of business success?" Hence, this research paper is one of the attempts to study the successful succession drivers involving a national wide company successor in Indonesia based on successful family business succession's model by Prior (2012) and further contribute to the body of knowledge and enhance the understanding of the family business succession planning process. First, this research paper examines the theoretical framework used as a reference for the study. Then, to get answers of the research question, the methodology used is outlined, along with a description of the selected key respondents. After that, findings are discussed based on five key dimensions successor-related factors, incumbent-related factors, family-context related factors, business-context decisions, structured-agreement system. Finally, the major contributions, limitations of the study, and future research recommendations are highlighted.

\section{Literature Review}

Venter, Boshoff, \& Maas (2005) developed a model of successor-related factors consist of the willingness of the successor to take over the business, the preparation level of the successor, and the relationship between the owner-manager and successor. The predecessor chooses the successor based on their willingness to take over the business with potential gains from the business; trust in the successor's ability; and the alignment of intentions and the personal needs. On the other hand, it also depends on family harmony, for instance, the relation between the predecessor and the owner-manager and the successor.

Even though Venter's model incorporates the successor-related factors of a successful succession process, it does not complete the significant aspects of the whole succession process, for instance, incumbent-related factors and the environment in which business operates (Prior, 2012). Furthermore, he added that how incumbents make decisions about the type of succession they intend to engage in such as intra-family succession, out of family succession, or no succession are still not clear. Whereas, this decision-making process is important because the way that owner plans, manages and executes the succession of a firm is intrinsically linked to their decision about the type of transition they intend to engage in, can have an effect in how the succession process is evaluated, and the financial viability of the family and the business. 
A family business is considered successful when they can separate the family matters and business matters (Poza, 2010; Prior, 2012); when they move towards professionalism (Stewart \& Hitt, 2012); when they create family councils and creeds (Prior, 2012); when they make distinctions between the division of profits and assets (Lane, Astrachan, Keyt, \& McMillan, 2006; Prior, 2012); when they increase the size of the business (Bruce \& Picard, 2006; Prior, 2012); and finally, when there is a willingness of the successors to join the business (Poza, 2010; Prior, 2012).

Under the business-context factors, Prior (2012) argues that the incumbent chooses profit to succession when they don't trust he/she would sustain the business. In line with Hall \& Nordqvist (2008) and Brockhaus (2004), Prior (2012) finds similar decision made by incumbents by hiring professional management when the successions don't take interest in the company. He further states that incumbent also prefers to sell the business instead of passing over to the next successor when the amount offered is big enough.

It is crucial to set up an agreement between shareholders in the family business succession process before the succession takes place (Poza, 2010; Prior, 2012) to avoid conflicts between siblings and/or other shareholders.

\section{Methodology}

\subsection{Research Design}

A case study is an observational request that examines a contemporary wonder top to bottom and inside its certifiable setting, particularly when the limits amongst marvel and setting may not be unmistakably apparent (Yin, 2014). According to Bungin (2012), a case study is a technique to describe in-depth an individual, a group or a phenomenon. Creswell (2014) defined a case study as an in-depth analysis of a case by researches to gather data through varies sources and methods over a sustained period of time. In addition, he added that the case is usually in the form of a program, event, activity, process, or one of more individuals which bounded by time and activity. As for Zikmund, Babin, Carr, \& Griffin (2010), they referred a case study as a description of a particular person, group, organization, or event that face a situation in business context. Hence, the case study is used to generate theory (Woodfield, Shepherd, \& Woods, 2017)

In addition, this study employed a multiple case analysis which enables the researcher to explore differences within and between cases to replicate findings across cases (Yin, 2014; Bizri, 2016; Woodfiel et al, 2017). Since comparisons are to be drawn, it is imperative that the cases are chosen carefully so that the researcher can predict similar results across cases, or predict contrasting results based on a theory (Yin, 2014; Boyd, Royer, Pei, \& Zhang, 2015).

\subsection{The Key Respondents}

Creswell (2014) proposes four to five samples for a case study since too many samples with the same results are a waste of resources and time. Key respondents are individuals whose social positions in a research setting give the researcher specialist knowledge about other people, processes or happenings that is more extensive, detailed or privileged than ordinary people, and who are particularly 
valuable sources of information to a researcher, not least in the early stages of a research (Prior, 2012; Yin, 2014). There were four key respondents in this research, based in Jakarta and Semarang, Indonesia. The lists of key respondents were:

Table 1: List of Cases and Respective Industries

\begin{tabular}{|l|l|l|l|l|}
\hline Cases & Resp ID & Name of the Company & Industry & Generation \\
\hline 1. & $\mathrm{AB}$ & tvOne & Media & $3^{\text {rd }}$ Generation \\
\hline 2. & $\mathrm{MY}$ & Optik Nusantara & Optical & $2^{\text {nd }}$ Generation \\
\hline 3. & $\mathrm{RB}$ & Global Mediacom & Media & $2^{\text {nd }}$ Generation \\
\hline 4. & MD & Dynamic Autosound & Car audio & $2^{\text {nd }}$ Generation \\
\hline
\end{tabular}

The criteria of the data collected are: the family businesses members must have attempted, completed or have intention to enter the succession process, whether it is failed or success. Furthermore, the family business must have a turnover greater than IDR 35 million per year and have more than five (5) employees.

\subsection{Analysing the data}

A cross-case synthesis is a technique only applied to multiple cases with at least 2 cases and the findings liable to be more vigorous than conducting with a singlecase (Yin, 2014).

In this research, data triangulation is used to adopt the multiple references of information as to ensure the validity of the research. The data were collected from the journal articles and four case studies. First, the data were analysed within-case to find out whether they were in line with the theories being used. Second, once all the data were analysed within-case, then the cross-case analysis were conducted. Finally, a discussion was developed to find the agreement between the theories and informants

\section{Results}

\subsection{Within-Case Analysis}

\subsubsection{Case 1: AB}

$\mathrm{AB}$, who was born on April 22, 1979, is the current President Director as well as the CEO of tvOne. TvOne is an Indonesian privately owns national television station based in East Jakarta that has been a leading TV station over the past ten years. He started off as the vice president director in 2008 and was promoted to become the president director of tvOne in 2011. During his presence, tvOne's profit has increased by 30 percent in 2012 and another 10 percent in 2013. Before joining tvOne, he was given a choice to work in other industries but instead followed his heart and decided to join the television industry since he is more much interested in media. By then, his parents and his big brother have always been a big support. Being the heir, it doesn't mean he is treated royally. On the contrary, He is treated equally as any other employees and if by any chance he makes made a mistake, he also receive punishment. In addition, He also had experiences in two other companies, which were CEMEX (Cement Mexico) and ANTV (AndalasTelevisi). 
He graduated from Georgetown University, Washington DC, majoring in finance and international business. Then, he continued his education by taking master's degree in finance from Bantley University, Mc Callum Graduate School of Business.

He felt that the willingness of the successor is significant in the family firm. $\mathrm{He}$ stated that,

"Why should I start from zero when my family has been building this conglomerate business until now?"

He considered his company (tvOne) as his own family in addition to his real family. The whole company is under the supervision of his family because he does not fully trust professionals. Currently, his willingness to be the successor is based from the philosophy of the family which is Trimatra Bakrie (Indonesianness, Utilization, and Togetherness). He let lets the people decide whether or not he is eligible to lead and so far he has been doing a great job. In addition, he showed entrepreneurial skill by thinking differently, being friendly, brainstorming and innovating. During the succession process, his parents challenged him to work using his own techniques. However, when it comes to decision making they are still involved in meetings by giving suggestions and advice. He fulfilled his parents' expectations by making tvOne the number one news channel for 7 (seven) years. He believed that this is because the incumbent played a big role in the succession process by applying ways which it feels right. His leadership style is family-oriented which means he believes in winning the hearts of people, even if they are his own staff.

They differentiate business meetings and Sunday lunches because the meetings are strictly professional. Having a big family does not complicate the succession process as they have many businesses to be supervised. Nevertheless, they do not have a family council, but if he or other family members have any disputes, they can ask for advice from the mentors (Chairman of Bakrie Group). He does not point out that family business is the best form of business because he is aware that there are other equally successful businesses which are not under the control of a family rather managed by professionals. The toughest obstacle he has faced is that he was all of a sudden chosen to be the president director when he wasn't totally ready. By then, he made major mistakes that affect his confidence but also helped him to improve. He added that the professional management also helped him to improve throughout the process because they are familiar with the field. He said that there is a difference between the thinkers and the doers; in this case, he is placed in the position of the thinker while the professionals are the doers. For instance, when he recognizes an opportunity that he or his family may not be able to handle, he still takes it thinking that the professionals will be able to manage. Moreover, there are no formal agreements carried out by the family which affect the succession process. In his family, from the first generation to the second, they follow the Muslim rules which are dividing the inheritance based on gender. The male inherits 2 (two) parts of the total inheritance while the female inherits only 1 (one) part. Nonetheless, from the second generation to the third there is no structured agreement. The inheritance was just divided equally among the siblings. 


\subsubsection{Case 2: MY}

MY is the owner of Optic Nusantara. Optic Nusantara is the oldest and the leading optical shop for almost half a decade in Semarang. It is exactly located on Jalan Dokter Semarang and has been established since 1968. At that time, the optical shop was managed by the father with the help from his relatives. There were approximately 7 (seven) relatives who helped his father in operating the company. Since 1997, this optical shop has started opening branches, first in the same city and expanded to Jakarta, Depok and Semarang. Currently they have 20 (twenty) outlets all over Indonesia. MY is the first born-son out of 7 (seven) siblings. This is the reason why he was chosen to take over his family business. His father has been preparing him since the very young age by giving him small responsibilities for example; making him look after the shop, communicating with the customers and persuading them to make a purchase. He was technically involved in the business since he was in kindergarten. His father adopted Rasulullah's preaching; introducing commercial trade to the young. He decided to be involved in business because he wants to make his parents proud. Moreover, he was also looking for his own personal growth such as management skills.

He said that the willingness of the successor is very important in the family firm. He explained,

"Since the firm is very popular and has been standing for 65 years, it would be a dishonor to the family if there is no willingness in the part of successor to continue the business."

His willingness to be the successor arose from the mind-set which has been formed by his parents since a very young age. In general, every parent wants their children to move forward and be more successful as they grow. In addition, they also have a successful family business which is beneficial for both the successor and the business itself. Furthermore, he gained his parents trust and showed that he is eligible to be the successor by obeying his parents and always helping in the shop. Every day after school he was always there in the shop being a helping hand to his parents. In 1991 during his college year, he officially joined the business as the marketer and successfully expanded the business consistently throughout the years. His ability has resulted in his parents to put faith on him to take over the business entirely. After taking over the business, he imposes new techniques of his own which has reaped good statements from his parents.

During the transition process, his parents play a big role as mentor by pouring him with advice, guidance and knowledge. A different business world he is facing now made him a picky strategist. He took a suitable business culture from his father and left behind the old-fashioned technique that he felt was inappropriate to develop the business. However, there were strict boundaries set between the family and the business. Family gatherings are always held before the business meeting. Thus, having a big family does not complicate the succession process since they actually follow the principal of sharing, every sibling wants the other to succeed as well. 
Family council does not exist in the family of MY. Nonetheless, as they are following the principal of sharing, they become very close and care for each other. As a result, whenever a problem happens, all the family members will immediately hold a meeting and discuss. Every member has a right to give their opinions and suggestions, and the decision will be finalized by his parents. Growing in a family business environment with a united family, MY felt that family business is the best form of business. Compared to other forms of businesses, for instance, partnership, different families are involved and they have their own matter, while in the case of family businesses usually the people involved understand the difficulties every member is facing at that time.

The biggest obstacle that MY had been through is the employees that have been working there since he was very young, due to this; the employees feel that they have more seniority in terms of experience in working in the company even though MY is the leader. He stated that,

"The employees said that, I have been working here since you were a little kid, I am more senior and I have more knowledge than you do."

However, he neutralized the situation by explaining that he is currently the leader and that the employees should follow his command. Currently, there is no professional management team involved but each store has its own manager. The manager's job is to supervise and report monthly updates to MY. A written structured agreement does not exist in this company. Although, an unwritten agreement does exist between the siblings which function is to determine distribution of outlets, the prices of goods in each outlet, the salary of employees in each city, and the rules and regulations.

\subsubsection{Case 3: RB}

RB was born in Jakarta, Indonesia, on June 21, 1984. He is acting as Senior Vice President of Business Development at Global Mediacom. Global Mediacom which established in 1981, is the largest and the only integrated media, broadcasting, entertainment and telecommunication group in Indonesia with operations that encompass content production, content distribution, television and radio broadcasting, newspaper, magazine, tabloids, telecommunication operator, mobile content aggregrator, value added services provider, and IT system integrator. RB is known as a key figure behind the creation of the first series tokusatsu Indonesia, Garuda Satria BIMA.

Ever since he was a kid, he has been told to build his own business empire. His father stated that,

"I built Global Mediacom and Plaza Indonesia Royalty and you too RB, must build your own business." 
RB's father, had prepared him to be mentally strong since young. Therefore, he applied what his father had given him and has built his own business although still within the scope of Global Mediacom. His businesses are MNC Shop (homeshopping), Garuda Satria BIMA and Rakuten online shopping.After graduating from the Department of International Finance and International Economics at the American University in Paris, France, in 2007, he started working as an equity officer at Merrill Lynch in Tokyo, where his grandparents lived. His father asked him to come home and work in the Corporate Makes \& Partners Law Firm as an associate in order to study the regulation applies in Indonesia. After gaining knowledge, he then moved to Ernst \& Young Indonesia for transaction advisory position. In November 2008, he became the staff of PT Global Mediacom Tbk as Business Development Manager and Corporate Finance.

RB has a philosophy of life which is,

"Just because the father sells apple it does not mean that the children must follow their father's foot step in the family business, even though they actually have potential to sell cars and open a car showroom. The moral of the story is they must follow their passion."

Every person has capacity and ability that needs to be explored because he believes every single individual is unique and special. According to $\mathrm{RB}$, the willingness of the successor matters, but it is more important to explore our own self-ability and self-competence. He mentioned that,

"We never know our capability until we explored. Try everything. Who knows we could sell apple, car and apparel at the same time."

The willingness to be the successor is shaped from the environment. When he was a teenager, he went to Swiss to study in order to find his true-self that formed him to be as he is right now. In addition, his passion and high dedication made him want to contribute more to the country. He did not want to become a mere entrepreneur, but an entrepreneur with positive impact to the society. RB showed his potential that he is eligible to be the successor by strengthening the social value he held. He stated that,

"Our media reach is 240 (two hundred and forty) million, it is more than half population in Indonesia. If we really focus and pour our hearts to the business, I believe it can change people's mind. That is why I created Bima Satria Garuda for children education program."

Never give up is a key success in the business world. He showed his entrepreneurial skill by maintaining discipline, knowledge and time-management. Moreover, he mentioned that persistency and enthusiasm is needed for surviving in this business. He stated,

"To be the world champion is they who step outside from their comfort zone. This is by showing persistency, spirit and willingness that will never fade away." 
His father always gives him freedom to work with his own techniques and knowledge. His father never comes in between and he lets RB learned by his own experience. However, challenges were given by Mr. Harry as he is the leader and mentor of RB. The structure of business and his ability to take over the company might have made the predecessor feel happy. However, RB believed that satisfaction is the beginning of downfall. He felt that he needed to stay foolish and stay hungry although his predecessor might seem pretty satisfied with his work. The incumbent did not play a big role in the succession process because he barely communicated with his parents. However, his Japanese-Indonesian blood dominated over his personality. Without being taught, he always has a high expectation of himself. Since he carried the genes of his mother, he was quite strict in managing people and his employees should reach the goals. Boundaries were set because they rarely have Sunday lunches and even if he attends the Sunday lunch his family and he never discusses business matter. Although, it is a must for him to attend birthdays and break-fasting. He did not have a big family thus; it did not complicate the succession process. He only has one sibling whose interest is different from him. Family council does not exist in the family business and the decision maker is his father. Nevertheless, he felt that having a family council is important but in their case he mentioned that his father has experienced enough therefore, there is no family council in the company.

According to him, family business is the worst form of business because it involves emotional attachment. In a family, not everyone can be happy by the decision he takes. Furthermore, he stated that if you want to make everyone happy, you have to be like our former president of the Republic of Indonesia, Susilo Bambang Yudhoyono. Building his own business, he has the freedom to do whatever he wants, but in the case of family business he has to follow the existing business in the family. He said that he did not find any obstacles during the transition process although for him every day is a challenge because he has to fulfill his target. Nonetheless, the obstacle he is facing now is the slow macro-economic growth. The professional management team is important in the success of the company but the leader also has a big impact. For instance, if the leader leads well the employee will be able to follow and succeed, but if the leader fails in giving example then obviously the employee will fail as well. The board members are like fuel to the company. They take decision, manage the employees and analyze the market. In the Global Mediacom, there is no structured agreement for family because he has built his own business. Thus, it makes him the major shareholder for that business.

\subsubsection{Case 4: MD}

MD is the owner of Dynamic Autosound which is one of the most well-known car audio shop in Jakarta. It has been established since 1980 and located in Boulevard Kelapa Gading, North Jakarta. At that time, the car audio shop was managed by the father and his wife. In the year 2000, this car audio shop has developed and opened a new branch in the same city. More expansion occurred in the year of 2000, and 
they continued by opening 2 (two) branches in Kemayoran, Central Jakarta. They currently have 4 (four) outlets in total.

As the second generation of the family, MD had been prepared to be the successor by his father. In the year 1995, his father started to let him involve in the business by teaching him the basic knowledge about car audio and the shop itself, for instance; listening to audio properly, making him look after the shop, handling multi-personality customer, and learning how to make customer satisfied with the service. The car audio encountered rapid development in the year of 2000, thus making it very popular as the trending topic for business and lifestyle. By then, many car audio specialists from all over the world came and conducted seminars in Jakarta. MD diligently joined the seminars to improve knowledge and skills in car audio.

He mentioned that the willingness of the successor is very important in the family firm. He explained,

"The car audio business in here is highly prospective due to the huge number of car existed. Moreover, this firm has been standing for 35 years, many people know us, trust us and delighted with our service."

His willingness to be the successor arose from his passion towards car and audio since young. He explained that although he grew in this environment, it is impossible to continue the business until today if he does not have passion. Furthermore, he gained his parents' trust and showed that he is eligible to be the successor by obeying his parents and always helping in the shop. He stated that,

"It is easy to win my parents' heart. Be an obedient and a responsible person. Open the shop clock in and close the shop on time. I always repeat this cycle until my parents felt I deserve to have their trust."

In the course of transition process, his parents played a big role as mentor; pouring him with knowledge, guidance and advice. Throughout 5 (five) years, from 1995 until 2000, he learned not only the basic but the company as a whole. Every activity was supervised directly by his parents. In the year 2000 until 2004, he was given the responsibility to look after one shop. He mostly did the operational management such as controlling staff performance and works' result, and dealing with customer. In the year 2004, his parents finally allowed him to take over the business. The ten years training with his parents is making him very grateful because without them it is impossible to be as successful as he is now.

Under the control of MD, he took a suitable business culture from his father and left behind the old-fashioned technique that he felt was inappropriate to develop the business. He also developed a better system that will not only beneficial for the business but for the high satisfaction of customer as well for example; improving the quality by accepting orders only according to the ability of the employee. In addition, he renewed the employee welfare system so that employee will feel happy 
and safe working in the firm. He explained that with the changes he made to the company, his parents always support him and never complain. One advice from his dad that embedded on his head is,

"You need to maintain the reputation of the family firm in the eye of customers and suppliers, if they trust you, they will make purchase even though you do not have money."

There were strict boundaries set between the family and the business. On Sunday lunch they avoid talking about business at all, for them it is a time for family to relax and to be at peace. However, if one of the family members wants to talk about business, he needs to report in advance. Furthermore, it is okay to talk about business but not too much and too deep. In addition, having 4 (four) siblings did not make the process to be the successor complicated because his father trusted him and saw his passion as a potential since he was a little. In other words, MD was the 'prominent' amongst his siblings, therefore he is selected as the successor. Family council does not exist in the family firm of MD. As a result, whenever a problem happens, all the family members will immediately hold a meeting and discuss. Every member has a right to give their opinions and suggestions, and the decision will be finalized by his parents. Growing in a family business environment shaped him to be a critical thinker. He did not point out that family business is the best form of business; he thought that there is always pros and cons in every form of business. He mentioned,

"There is always pros and cons in every form of business. One thing we should have in business is maturity. Maturity leads us to be wise, and wise make people successful."

The toughest obstacle that MD had been through is the difficulty to manage financial management. The moment he took over the company financial management breakdown occurred, and he anticipated it by renewing the whole financial system. Currently, there are no professional management teams involved due to insignificant impact in car audio shop. Basically car audio shop only needs installer assistant which is hard to find nowadays. In addition, a written structured agreement does not exist in this company.

\subsection{Cross-Case Analysis}

\subsubsection{The successor-related factors that affected the succession process}

There are four responses regarding to this factor. Venter et al. (2005) stated that there are 2 (two) key factors which directly affect the succession process: the preparation of the successor and the willingness of the successor to take over business.

In case 1 and case 3, the preparation was done by sending the successor to complete his education and let them experience in other companies before joining the business. However, in case 2 and case 4, the preparation was held by introducing the business to the successor from the very young age. In conclusion, there are two 
methods used in preparing the successors which are education and experience from other companies and engaging with the business from young age. Furthermore, the 4 (four) cases expose that the willingness of the successors to join the company is based on their personal necessities. The successors need to be highly motivated to be involved in the business in order to carry on the legacy left by the predecessor.

These findings are in line with Le-Bretton Miller et al. (2004) and Prior (2012) findings that successor-related factors are successor motivation, nurturing and development, outside work experience, formal education and training programs.

\subsubsection{The incumbent-related factors that affected the succession process}

A critical variable in determining whether a firm is producing progress in succession planning is the presence of a successor, whom the incumbent can trust and whom he or she believes is willing to take over the business (Pontet, 2008). This theory aligns with the researcher findings of the 3 (three) case studies that all the successors have shown their ability to become the eligible successors, such as being an obedient and a responsible person, and contributing improvement to the company.

The incumbent's perceived satisfaction of the process is directly related to the successor's willingness to take over the business (Sharma, Chrisman, \& Chua, 2003). The successor of the 4 (four) cases revealed that throughout the transition process they successfully achieved goals given by the predecessor resulting in confidence to take over the company.

The similarities occurred in the case 1,2 and 4 that the incumbent's played a big role over the succession process. However in case number 3, the incumbent did not play a big role in the succession process because he barely communicated with his parents. However, his Japanese-Indonesian blood dominated his personality. Without being taught, he always has a high expectation of himself. In accordance to Sharma, Chrisman, \& Chua (2003), willingness can be shown by the incumbent making a formal or informal succession plan because it indirectly obligates the incumbent to pass on the business to the successor.

To conclude, it is clear that the incumbent has a significant influence in the succession process. The incumbent is needed to help and stimulate the succession process and they also need to be present effectively because their behavior and principles will determine the success of the process.

\subsubsection{The family-context related factors that affected the succession process}

From the findings, it is showed that all families held business meetings professionally and have separate Sunday lunches. According to Poza (2010) families who are capable to distinguish between business and family issues have a better chance of having a successful succession process. Setting boundaries between family and business leads families to the benefit of encouragement of a successful succession. Moreover, expansion of the family business is also related 
to the family context factor during the succession process. Based on Bruce \& Picard (2006), the size of family might influence the number of dispute, rivalry and competition among family members. If the amount of family members involved is bigger than the capacity of the business, this event may lead to disputes. Whereas, if the company has done expansion with a little amount of family members joining, dispute may occur as well. Based on the result of four case studies, three of the families increase the business equivalently to the family members that wish to involve in the firm. The results from the findings suggest that professionalization may bring disadvantage to some businesses because they prefer to be structurally free in order to have flexibility on decision making. Moreover, in the four case studies, there is no family council employed in the firm as they usually make business key decisions through informal family meetings. This is supported by Melin \& Nordqvist (2007) view that corporate practices should not be implemented in family firm, as this is the characteristics that make them effective.

The main benefits of a family business system are the relationship between the family and its business, the loyalty, management style and common interest and the effect they may have on the succession process (Poza, 2010). RB pointed out that the family business is the worst form of business while the other three cases mention that family business is good enough for them. This brings to the conclusion that the loyalty to family business has been embedded in the mindset of $A B, M Y$ and MD.

\subsubsection{The business-context decisions and factors that affected the succession process}

There are three obstacles faced during the succession process. These are faced by $\mathrm{AB}, \mathrm{MY}$ and MD, However, RB faced daily challenges which are not related to the succession process. The obstacle faced by $A B$ is that he was not prepared when he was chosen as the president director of the business. This caused him to make mistakes which allowed him to learn from it in order to be a better leader.

While the obstacle MY faced was that the employees who served longer than him felt that more knowledgeable and experienced than MY. This made MY felt intimidated and clarified to the employees that even though he was younger in age and experiences, he is still chosen as the leader. Thus, the employees should follow his ways.

Furthermore, since there were problems in the existing financial system, MD faced some difficulties. However, he managed to renew the financial system during the succession period which proved him to be competent enough to take over the company. Other than those, RB faced another obstacle which was the slowdown in economic growth. He has to reach a certain target every day which became a challenge for him with the current economy. Nonetheless, his solution was to work harder every single day and never give up.

Other than the obstacles faced during the succession process, the professional management team is also a factor linked to the business context element which affects the succession process. There are many types of professional management teams around the world. According to $\mathrm{AB}$, the professional management team in his company really helped him during the succession process because they have 
experiences in that field. Additionally, RB's company also has a professional management team which he felt has a big impact on the company.

While in MY's business, there is no professional management team but every division has their own managers. The same goes In MD's company, there is also no management team because it has insignificant impact in a car audio shop. To conclude, having a management team depends on the business a person owns and how the person operates the business.

\subsubsection{The structured agreements that the family implemented affected the succession process}

Shareholders' agreement is something that may act as a form of governance between the shareholders-family business relationships (Poza, 2010). Even though $\mathrm{AB}$ and $\mathrm{RB}$ owns a conglomerate company, there are no formal agreements for their business because AB's family follows Muslim rules which are dividing the inheritance based on gender. The male inherits 2 (two) parts of the total inheritance while the female inherits 1 (one) part; and RB has built his own business. Thus, it makes him the major shareholder for that business.

Meanwhile, in MY's and MD's business, an unwritten agreement exists which in both cases is to determine the distribution of outlets, the prices of goods in each outlet, the salary of employees in each city, and the rules and regulations. Additionally, in MD's case, the family firm implements informal agreements made by discussion in family meetings.

\section{Conclusions}

The findings have answered five secondary questions. The determinants of successful family business succession are managing a complex relationship system of successor and incumbent related factors, family context that conducting formal meetings and involving a professional management team into business, and having a structured agreements system.

Preparation and willingness of the successor are found to be the main reason for the successful succession process and it also shows high profitability (Foltz \& Marshall, 2012). In addition, the findings show that the incumbent is ready to let go of the business if they (AB, MY and MD) proved to be competent enough to take over the business.

The incumbent's expectation was gained by those four business owners which proved themselves as competent and thus, the incumbents have the willingness to pass on the business to the successor. This theory proved that if the successor earns the incumbent's trust, the incumbent will easily let go of the business. Other than those two elements, the family context impacts on the succession process. Based on the results, it show that all families held business meetings professionally and have separate non-business matters on Sunday lunches. According to Poza (2010) families who are capable to distinguish between business and family issues have a better chance of having a successful succession process. Setting boundaries 
between family and business leads families to the benefit of encouragement of a successful succession.

The expansion of family business may lead to chaos but in the three cases, it proves to be helpful for leading existing businesses. In the case of RB (Global Mediacom), he only has one sibling, therefore he can't say whether having an expanding family is complicated. In accordance to Bruce and Picard's theory, the number of businesses must be proportional to the number of family members; this will not cause conflict in the succession process. A family council commonly exists in a big family with a big number of businesses to avoid commotion in the family. In these four cases, they do not have a family council; instead they make the decision through informal family meetings.

There are different obstacles faced in the business by those four informants. These include inadequate preparation, seniority, target achievement, and the financial system. Those four informants faced different problems but managed to overcome those challenges during the succession process. Furthermore, the professional management team also affects the succession process as confirmed by $\mathrm{AB}$ and $\mathrm{RB}$ because the team has been a big help for them. While in MY's business, a management team did not exist, instead there were managers in every store. In the case of MD's business, it does not need a professional management team because of the industry the company is working in.

In order for a family business to go through more generations, it needs a successful succession process. Therefore, they need to know the determinants to a successful succession process. The determinants should not only know the determinants but also apply them to the business. For instance, family council and structured agreements actually have impacts to a successful succession process. However, the four informants did not have a family council and a structured agreement. Even though it does not become a problem for them, it may cause failure in some succession processes. Hence, every family business has a different case, therefore, understanding the characteristics of the business is important in order to conduct a successful succession process.

\section{References}

Angelina, S. \&. (2013). Studi Deskriptif Pengelolaan Pengembangan Usaha Plastic Houseware pada PT Multiplast Indojaya (Studi Kasus pada Aspek Pemasaran). Agora, 1 (2).

Bizri, R. (2016). Succession in the family business: drivers and pathways. International Journal of Entrepreneurial Behavior \& Research , 22 (1), 133-154. https://doi.org/10.1108/ IJEBR-01-2015-0020

Boyd, B., Royer, S., Pei, R., \& Zhang, X. (2015). Knowledge transfer in family business successions: Implications of knowledge types and transaction atmospheres. Journal of Family Business Management , 5 (1), 17-37. https://doi.org/10.1108/JFBM-05-2014-0009

Bozer, G., Levin, L., \& Santora, J. (2017). Succession in family business: multisource perspectives. Journal of Small Business and Enterprise 
Development , 24 (4), 753-774. https://doi.org/10.1108/JSBED-10-20160163

Brockhaus, R. (2004). Family Business Succession: Suggestions for future research. Family Business Review , 17 (2), 165-177.

Bruce, D., \& Picard, D. (2006). Making Succession a Success: Perspectives from Canadian small and medium-sized enterprises. Journal of Small Business Management , 44 (2), 306-309.

Bungin, B. (2012). Analisis Data Penelitian Kualitatif. Jakarta: Raja Grafindo Persada.

Creswell, J. W. (2014). Research design: Qualitative and quantitative approaches. Thousand Oaks, CA: SAGE.

de Pontet, S. B. (2008). Using theories of control and self-regulation to examine the leadership transition between a parent and child in family-owned businesses. Thesis Dissertation. Retrieved from https://spectrum.library.concordia.ca/975607/

Hall, A., \& Nordqvist, M. (2008). Professional Management in Family Businesses: Toward an Extended Understanding. Family Business Review , 21 (1), 5169. https://doi.org/10.1111/j.1741-6248.2007.00109.x

Lane, S., Astrachan, J., Keyt, A., \& McMillan, K. (2006). Guidelines for family business board of directors. Family Business Review , 19 (2), 147-167.

Le-Bretton Miller, I., Miller, D., \& Steier, L. P. (2004). Toward an integrative model of effective FOB succession. Entrpreneurship: Theory and Practice, 28 (4), 305-328. https://doi.10.1111/j.1540-6520.2004.00047.x

Maciel, A., de la Garza Ramos, M. I., Aguilar, J. L., \& Reyna, J. M. (2015). The influence of family relationships in the succession: A factorial analysis of Mexican enterprises. Journal of Family Business Management , 5 (20), 238256. https://doi.org/10.1108/JFBM-11-2014-0036

Melin, L., \& Nordqvist, M. (2007). The reflexive dynamics of institutionalization: the case of family business. Strategic organization , 5 (3), 321-333. https://doi.org/10.1177/1476127007079959

Poza, E. (2010). Family Business (3rd ed.). Ohio: South-Western Cengage Learning.

Prior, S. (2010). The Determinant of Successful Family Business Succession. Thesis Dissertation. Retrieved from: https://repository.up.ac.za/handle/2263/23268

Sharma, P., Chrisman, J., \& Chua, J. (2003). Predictors of satisfaction with the succession process in family firms. Journal of Business Venturing , 18 (5), 667-687. 
Stewart, A., \& Hitt, M. (2012). Why can't a family business be more like a nonfamily business? Modes of Professionalization in Family Firms , 25 (1), 5886.

Venter, E., Boshoff, C., \& Maas, G. (2005). The Influence of Successor-Related Factors on the Succession Process in Small and Medium-Sized Family Businesses. Family Business Review, 18 (4), 283-302.

Woodfield, P., Shepherd, D., \& Woods, C. (2017). How can family winegrowing businesses be sustained across generations? International Journal of Wine Business Research , 29 (2), 122-139. https://doi.org/10.1108/IJWBR-122015-0052

Yin, R. K. (2014). Case Study Research Design and Methods (5th ed.). Thousand Oaks, CA: SAGE.

Zikmund, W., Babin, B., Carr, J., \& Griffin, M. (2012). Business Research Methods (9th ed.). Singapore: Cengage. 